\title{
IMPLEMENTASI KEBIJAKAN PENGELOLAAN PASAR RAKYAT PADA PASAR BUDURAN KABUPATEN SIDOARJO
}

\author{
${ }^{1}$ Erry Pratama, ${ }^{2}$ Diana Hertati \\ 1,2Program Studi Administrasi Publik Fakultas IImu Sosial dan IImu Politik \\ Universitas Pembangunan Nasional "Veteran" Jawa Timur \\ erryp7@gmail.com, diana.adne21@gmail.com \\ Surabaya, 60294, Indonesia
}

\begin{abstract}
The existence of a market is one indicator of the economic activities of the people in an area. This research is motivated by the lack of optimal management of the Buduran Market by the Industry and Trade Office of Sidoarjo Regency. It can be seen from the supporting facilities and infrastructure in the Buduran Markets which are still inadequate and poorly maintained. This study aims to determine how the implementation of community market management policies in Buduran Market, Sidoarjo Regency. The research method used in this article is a descriptive research method with a qualitative approach by using a qualitative approach. The results show that the implementation of the people's market management policy has been implemented, but there are still problems in its implementation. The conclusion of this research is the implementation of the people's market management policy in its implementation is still not optimal, this can be seen from the indicators of the success of policy implementation.
\end{abstract}

Keywords: Market Management; Public Market; Policy Implementation

\begin{abstract}
Abstrak
Keberadaan sebuah pasar merupakan salah satu indikator dalam kegiatan ekonomi masyarakat di suatu wilayah. Penelitian ini dilatarbelakangi oleh kurang optimalnya pengelolaan Pasar Buduran oleh Dinas Perindustrian dan Perdagangan Kabupaten Sidoarjo. Terlihat dari fasilitas dan sarana prasarana pendukung yang ada di Pasar Buduran masih kurang memadai dan kurang terawat. Penelitian ini bertujuan untuk mengetahui bagaimana implementasi kebijakan pengelolaan pasar rakyat pada Pasar Buduran Kabupaten Sidoarjo. Metode penelitian yang digunakan dalam artikel ini adalah metode penelitian deskriptif dengan pendekatan kualitatif. dengan menggunakan pendekatan kualitatif. Hasil penelitian menunjukkan bahwa implementasi kebijakan pengelolaan pasar rakyat telah dilaksanakan tetapi masih terdapat permasalahan dalam pelaksanaannya. Kesimpulan dari penelitian ini adalah implementasi kebijakan pengelolaan pasar rakyat dalam pelaksanaannya masih belum optimal, hal ini dapat dilihat dari indikator-indikator keberhasilan implementasi kebijakan.
\end{abstract}

Kata Kunci: Implementasi Kebijakan; Pasar Rakyat; Pengelolaan Pasar 


\section{PENDAHULUAN}

Dalam rangka memenuhi kebutuhan hidup sehari-hari manusia tidak dapat memenuhinya secara mandiri. Oleh karena itu, manusia perlu melakukan interaksi sosial dengan manusia lainnya sehingga kebutuhan hidupnya dapat terpenuhi. Salah satu tempat yang digunakan untuk mencari kebutuhan hidup sehari-hari tersebut adalah pasar. Menurut Nyoman dikutip Martha \& Ika (2019) pengertian pasar secara sempit adalah suatu tempat pertemuan antara penjual dengan pembeli untuk melakukan transaksi. Pendapat lain menurut Efendi dan Syifa (2019) pasar termasuk tempat umum yang merupakan sarana dimana orang banyak terkumpul dan mengadakan interkasi atau hubungan dengan sesamanya, salah satu bentuk interaksi tersebut bertemunya para penjual dan pembeli. Lebih lanjut menurut Saputra, dkk. (2019) dalam hakikatnya pasar merupakan tempat bertemunya penjual dan pembeli, dengan kata lain syarat di namakannya pasar adalah adanya penjual (pedagang), pembeli dan tentunya barang yang di perjual belikan.

Ada dua jenis pasar, pasar tradisional dan pasar modern. Pasar tradisional merupakan penggerak ekonomi masyarakat (Masitoh 2013). Kemudian menurut Suprapto dalam Yuliani, dkk. (2016) pasar tradisional adalah tempat yang mempunyai unsur-unsur sosial, ekonomis, kebudayaan, politis dan lain-lain, tempat pembeli dan penjual saling bertemu untuk mengadakan tukar- menukar, untuk menjual barang- barang kebutuhan sehari-hari secara resmi diakui oleh pemerintah. Sedangkan pasar modern tidak banyak berbeda dari pasar tradisional, namun pasar jenis ini penjual dan pembeli tidak bertransakasi secara langsung melainkan pembeli melihat label harga yang tercantum dalam barang (barcode), berada dalam bangunan dan pelayanannya dilakukan secara mandiri (swalayan) atau dilayani oleh pramuniaga.

Kabupaten Sidoarjo adalah sebuah kabupaten yang terletak di Provinsi Jawa Timur. Kabupaten ini berbatasan dengan Kota Surabaya dan Kabupaten Gresik di utara, Selat Madura di timur, Kabupaten Pasuruan di selatan, serta Kabupaten Mojokerto di barat. Bersama dengan Gresik, Sidoarjo merupakan salah satu penyangga utama Kota Surabaya, dan termasuk dalam kawasan Gerbangkertasusila. Kabupaten Sidoarjo yang terkenal dengan kota perdagangan dan industri membuat kondisi tersebut harus membutuhkan kelancaran distribusi bahan-bahan pokok maupun bahan tersier. Kabupaten Sidoarjo memiliki peluang untuk mengembangkan sektor informal, salah satunya adalah pasar. Apabila peluang tersebut dikembangkan dan dikelola dengan baik, maka akan menghasilkan kemajuan ekonomi yang sangat pesat dan dapat menunjang dalam kesejahteraan masyarakat di daerah tersebut.

Jumlah pasar tradisional yang ada di Kabupaten Sidoarjo berjumlah 19 pasar, Berikut merupakan daftar pasar tradisional yang ada dan terdaftar di Disperindag Kabupaten Sidoarjo. 


\section{Journal Publicuho}

ISSN2621-1351 (online), ISSN 2685-0729 (print)

Tabel 1. Daftar Pasar Tradisional di Kabupaten Sidoarjo

\begin{tabular}{|c|c|c|c|c|}
\hline No & $\begin{array}{l}\text { Nama Pasar } \\
\text { Tradisional }\end{array}$ & Alamat Lokasi Pasar & Pengelola & $\begin{array}{l}\text { Jumlah Stan, } \\
\text { Kios \& Los }\end{array}$ \\
\hline 1. & Pasar Sidoarjo & Jl. Sunandar Priyo Sudarmo & $\begin{array}{l}\text { Disperindag Kabupaten } \\
\text { Sidoarjo }\end{array}$ & 2619 \\
\hline 2. & Pasar Buduran & Jl. Raya Buduran & $\begin{array}{c}\text { Disperindag Kabupaten } \\
\text { Sidoarjo }\end{array}$ & 76 \\
\hline 3. & Pasar Krian & Jl. Raya Krian No. 1 & $\begin{array}{c}\text { Disperindag Kabupaten } \\
\text { Sidoarjo }\end{array}$ & 830 \\
\hline 4. & Pasar Wonoayu & Jl. Raya Wonoayu & $\begin{array}{c}\text { Disperindag Kabupaten } \\
\text { Sidoarjo }\end{array}$ & 151 \\
\hline 5. & Pasar Watutulis & Desa Temu, Prambon & $\begin{array}{l}\text { Disperindag Kabupaten } \\
\text { Sidoarjo }\end{array}$ & 140 \\
\hline 6. & Pasar Prambon & Jl. Raya Prambon & $\begin{array}{l}\text { Disperindag Kabupaten } \\
\text { Sidoarjo }\end{array}$ & 459 \\
\hline 7. & Pasar Tarik & Desa Tarik & $\begin{array}{l}\text { Disperindag Kabupaten } \\
\text { Sidoarjo }\end{array}$ & 61 \\
\hline 8. & Pasar Taman & Jl. Stasiun No. I, Taman & $\begin{array}{c}\text { Disperindag Kabupaten } \\
\text { Sidoarjo }\end{array}$ & 914 \\
\hline 9. & Pasar Sukodono & Jl. Raya Sukodono & $\begin{array}{c}\text { Disperindag Kabupaten } \\
\text { Sidoarjo }\end{array}$ & 548 \\
\hline 10. & Pasar Porong & Jl. Bhayangkari, Porong & $\begin{array}{l}\text { Disperindag Kabupaten } \\
\text { Sidoarjo }\end{array}$ & 2840 \\
\hline 11. & Pasar Tulangan & Jl. Raya Tulangan & $\begin{array}{c}\text { Disperindag Kabupaten } \\
\text { Sidoarjo }\end{array}$ & 289 \\
\hline 12 . & Pasar Bulang & Desa Bulang & $\begin{array}{c}\text { Disperindag Kabupaten } \\
\text { Sidoarjo }\end{array}$ & 152 \\
\hline 13. & $\begin{array}{c}\text { Pasar } \\
\text { Krembung }\end{array}$ & Desa Kandangan & $\begin{array}{l}\text { Disperindag Kabupaten } \\
\text { Sidoarjo }\end{array}$ & 350 \\
\hline 14. & $\begin{array}{c}\text { Pasar } \\
\text { Gedangan }\end{array}$ & $\begin{array}{l}\text { J. Raya Ketajen I, } \\
\text { Gedangan }\end{array}$ & $\begin{array}{c}\text { Disperindag Kabupaten } \\
\text { Sidoarjo }\end{array}$ & 648 \\
\hline 15. & $\begin{array}{c}\text { Pasar } \\
\text { Wadungasri }\end{array}$ & Jl. Raya Wadungasri I & $\begin{array}{c}\text { Disperindag Kabupaten } \\
\text { Sidoarjo }\end{array}$ & 727 \\
\hline 16. & $\begin{array}{c}\text { Pasar } \\
\text { Kedungrejo }\end{array}$ & $\begin{array}{l}\text { Jl. Brigjend Katamso 178, } \\
\text { Waru }\end{array}$ & $\begin{array}{l}\text { Disperindag Kabupaten } \\
\text { Sidoarjo }\end{array}$ & 770 \\
\hline 17. & Pasar Krian Baru & Jl. Basuki Rahmat, Krian & $\begin{array}{l}\text { Disperindag Kabupaten } \\
\text { Sidoarjo }\end{array}$ & 563 \\
\hline 18. & $\begin{array}{l}\text { Pasar Loak \& } \\
\text { Unggas }\end{array}$ & Desa Larangan & $\begin{array}{c}\text { Disperindag Kabupaten } \\
\text { Sidoarjo }\end{array}$ & 286 \\
\hline 19. & Pasar Sayur & Jl. Arteri Porong & $\begin{array}{c}\text { Disperindag Kabupaten } \\
\text { Sidoarjo }\end{array}$ & 50 \\
\hline
\end{tabular}

Sumber: Website Disperindag Kabupaten Sidoarjo diolah oleh Penulis (2020).

Berdasarkan tabel 1 diatas dapat diketahui bahwa Pasar Buduran merupakan Pasar yang dikelola langsung oleh Disperindag Kabupaten Sidoarjo. Di Kabupaten Sidoarjo pasar tradisional dibedakan menjadi 2 jenis yaitu, Pasar Rakyat dan Pasar Daerah. Pasar Rakyat adalah tempat usaha yang ditata, dibangun, dan dikelola oleh Pemerintah, Pemerintah Daerah, swasta, Badan Usaha Milik Negara dan/atau Badan Usaha Milik Daerah dapat berupa toko, kios, los, dan tenda yang dimiliki/dikelola oleh pedagang kecil dan menengah, swadaya masyarakat atau koperasi serta usaha mikro, kecil, dan menengah dengan proses 
jual beli barang melalui tawar-menawar. Pasar Daerah adalah pasar rakyat yang dimiliki, dikuasai dan dikelola oleh Pemerintah Daerah.

Pasar Buduran merupakan Pasar Rakyat yang dikelola langsung oleh Disperindag Kabupaten Sidoarjo. Pasar yang didirikan sejak jaman Belanda ini berdiri di lahan milik Pemerintah Kabupaten Sidoarjo dengan luas kurang lebih $1000 \mathrm{~m}^{2}$. Pasar Buduran terletak di Kecamatan Buduran Kabupaten Sidoarjo dan memiliki jam operasional pukul 05.30-21.00 WIB. Pasar yang terdiri atas dua bangunan memanjang tersebut letaknya relatif strategis. Yakni, berada persis di tepi Jalan Raya Buduran. Pengguna jalan bisa dengan mudah melihat bangunan pasar tersebut.

Dalam observasi yang dilakukan peneliti, Pasar Buduran pada saat ini kondisi bangunannya sudah sangat lawas. Kios satu dengan yang lain hanya dibatasi dengan tripleks. Di bagian tengah, berjejer lapak-lapak pedagang. Lapak-lapak itu ditata alakadarnya. Kesan kumuh pun terasa serta atap bangunan juga sudah banyak yang berlubang. Selain itu, banyak fasilitas-fasilitas yang kondisinya kurang memadai dan kondisi infrastruktur pasar perlu diperhatikan. Pasar Buduran juga tidak memiliki lahan parkir yang memadai. Lahan parkir terletak di depan pasar yang langsung berbatasan dengan jalan.

Beberapa fasilitas yang kurang memadai di Pasar Buduran menjadikan pasar sepi peminat, baik sepi pedagang maupun pembeli. Dari segi penerimaan retribusi pasar di Pasar Buduran juga mengalami penurunan selama beberapa tahun terakhir.

Tabel 2. Daftar Retribusi Pasar Buduran

\begin{tabular}{ccc}
\hline No. & Tahun & Jumlah Retribusi (Rp) \\
\hline 1. & 2018 & 20.817 .000 \\
\hline 2. & 2019 & 20.356 .000 \\
\hline 3. & 2020 & 17.318 .000
\end{tabular}

Sumber: Kantor Pengelola Pasar Buduran diolah oleh Penulis (2021).

Berdasarkan tabel 2 diatas dapat diketahui bahwa penerimaan retribusi pasar pada tahun 2018 sampai dengan 2020 mengalami penurunan. Penyebabnya adalah banyak stan kios dan los yang tutup dan juga tidak semua buka setiap hari karena kondisi pasar yang sepi pengunjung. Menurut petugas pengelola Pasar Buduran hal tersebut terjadi karena saat ini banyak pesaing baru pasar tradisional seperti munculnya pasar-pasar dalam skala kecil di sekitar pemukiman penduduk serta semakin tersaingi dengan kehadiran pasar modern maupun minimarket hingga supermarket. Salah satu penyebab masyarakat tidak memilih berbelanja di pasar tradisional saat ini adalah tata kelola pasar tradisional yang kurang baik, kondisi pasar dan juga fasilitas pasar yang kurang memadai. Kenyataan itu dinilai membuat para pengunjung pasar tradisional beralih memilih pasar modern yang menawarkan kenyamanan berbelanja. Penulis tertarik melakukan penelitian ini karena Pasar Buduran saat ini kondisinya tidak terawat dari segi pengelolaan dibandingkan dengan pasar tradisional 


\section{Journal Publicuho}

ISSN2621-1351 (online), ISSN 2685-0729 (print)

Volume 4 Number 2 (May-July), (2021)pp. 647-660

Accredited SINTA SK.NOMOR 28/E/KPT/2019

Open Access at:http://ojs.uho.ac.id/index.php/PUBLICUHO/index

DOI: 10.35817/jpu.v4i2.18090

yang ada di kecamatan yang lain di Kabupaten Sidoarjo. Hal tersebut tidak sesuai dengan Peraturan Daerah Kabupaten Sidoarjo Nomor 1 Tahun 2018.

Sebagaimana yang dimuat dalam Peraturan Daerah Kabupaten Sidoarjo Nomor 1

Tahun 2018 keberadaan pasar rakyat sebagai salah satu infrastruktur ekonomi daerah memiliki fleksibilitas yang tinggi dalam mewujudkan prinsip demokrasi ekonomi. Dalam hal ini pemerintah daerah memiliki tanggung jawab untuk melaksanakan perlindungan dan pemberdayaan pasar tradisional tersebut sebagaimana diatur dalam Peraturan Presiden nomor 112 tahun 2007 tentang Penataan dan Pembinaan Pasar Tradisional, Pusat Pembelanjaan dan Toko Modern.

Mengingat kondisi Pasar Buduran yang terlihat masih kurang dalam segi pengelolaan oleh pemerintah daerah serta adanya kebijakan Peraturan Daerah Kabupaten Sidoarjo Nomor 1 Tahun 2018 Pasal 3 tentang Pengelolaan Pasar Rakyat. Maka perlu adanya peran pemerintah Kabupaten Sidoarjo dalam mengatasi permasalahan tersebut. Hal ini bertujuan untuk menjaga eksistensi pasar tradisoinal agar tidak kalah saing dengan pasar modern. Beberapa masalah tersebut harus segera dibenahi mengingat fasilitas yang baik merupakan hal yang utama agar pengunjung lebih nyaman saat berbelanja. Jangan sampai masyarakat lebih memilih belanja di pasar modern ketimbang di pasar tradisional seperti Pasar Buduran. Karena masyarakat menganggap berbelanja di pasar modern kondisinya lebih bersih, tidak becek dan juga tidak bau. Meskipun keadaan pasar tradisional sedemikian parah, namun tetap saja keberadaan pasar tradisional tidak mungkin ditiadakan. Karena sebagian besar masyarakat masih berada dalam kondisi ekonomi menengah ke bawah, sehingga tidak memiliki daya beli yang cukup besar untuk terus-menerus berbelanja di pasar-pasar modern. (Sudrajat, dkk. 2018). Melihat kondisi pasar tradisional yang memiliki citra kurang baik, pemerintah merasa perlu adanya perubahan dan perbaikan yang dilakukan di setiap pasar tradisional.

Penelitian ini dilakukan untuk mengetahui implementasi kebijakan pengelolaan pasar oleh pemerintah Kabupaten Sidoarjo. Dalam menganalisis permasalahan ini peneliti menggunakan teori model implementasi dari George C. Edward III. Alasan peneliti menggunakan teori ini karena indikator teori relevan dengan fenomena yang ditemukan di lapangan yaitu masih terdapat masalah di komunikasi dan sumber daya berupa fasilitas. Selain itu teori Edward III juga membahas detail karena disetiap variabel terdapat indikator yang dapat mengukur keberhasilan sebuah implementasi kebijakan publik. Dalam mengkaji implementasi kebijakan publik, Edward III memulai dengan mengajukan dua pertanyaan, yakni: 1) What is the precondition for successful policy implementation?; 2) What are the primary obstacles to successful policy implementation?. Yang artinya Edward III tidak hanya berusaha menganalisis bagaimana implementasinya, namun juga bisa menangkap kondisi- 
kondisi pre-eksisting dan primary success. Sehingga hasil analisa implementasi dapat lebih menyeluruh.

Hasil penelitian ini juga dapat memberikan saran berupa solusi yang dapat dilakukan oleh pemerintah daerah, pengelola pasar, maupun pedagang untuk memperbaiki Pasar Buduran agar keadaan dan citranya menjadi lebih baik. Eksistensinya dapat terus terjaga dan dapat bersaing dengan pasar modern seperti tujuan yang diharapkan oleh pemerintah. Berdasarkan uraian tersebut maka peneliti tertarik untuk melakukan penelitian dengan tujuan untuk mengetahui implementasi kebijakan pengelolaan pasar rakyat pada Pasar Buduran Kabupaten Sidoarjo.

\section{METODOLOGI}

Penelitian merupakan proses pemecahan suatu masalah dengan melakukan suatu pendekatan dengan metode ilmiah untuk menyelesaikan permasalahan yang ada secara sistematis. Dalam melakukan sebuah penelitian, diperlukan metode penelitian yang sesuai dengan permasalahan dan tujuan yang sedang diteliti. Metode penelitian yang digunakan oleh peneliti adalah metode penelitian deskriptif dengan pendekatan kualitatif. Penelitian ini bertujuan untuk mengetahui Analisis Implementasi Peraturan Daerah Kabupaten Sidoarjo Nomor 1 Tahun 2018 Pasal 3 tentang Pengelolaan Pasar Rakyat Kabupaten Sidoarjo. Dari konsep tersebut yang diinginkan oleh penulis adalah suatu informasi dalam bentuk deskripsi. Hasil data yang akan diperoleh pada saat menggunakan metode penelitian deskriptif kualitatif berupa kata-kata, gambar, bukan angka-angka.

Moleong dikutip oleh Natsir (2017) menyatakan bahwa penelitian kualitatif adalah penelitian yang bermaksud untuk memahami fenomena tentang apa yang dialami oleh subjek penelitian (contohnya: perilaku, persepsi, motivasi, tindakan dan lain sebagainya) secara holistik dan dengan cara deskripsi dalam bentuk kata-kata dan bahasa, pada suatu konteks khusus yang alamiah dan dengan memanfatkan berbagai kaedah ilmiah. Lebih lanjut menurut Shidiq dan Choiri (2019:1) penelitian kualitatif adalah penelitian yang menghasilkan penemuan-penemuan yang tidak dapat dicapai dengan menggunakan prosedur statistik atau dengan cara kuantitatif. Penelitian kualitatif dapat menunjukkan kehidupan masyarakat, sejarah, tingkah laku, fungsionalisme organisasi, pergerakan sosial, dan hubungan kekerabatan. Beberapa data dapat diukur melalui data sensus, tetapi analisisnya tetap analisis data kualitatif.

Dengan demikian, berdasarkan uraian di atas penelitian ini menggunakan jenis penelitian deskriptif kualitatif yang isinya mendeskripsikan mengenai Implementasi Kebijakan Pengelolaan Pasar Rakyat Pada Pasar Buduran Kabupaten Sidoarjo. 


\section{Journal Publicuho}

ISSN2621-1351 (online), ISSN 2685-0729 (print)

Volume 4 Number 2 (May-July), (2021)pp. 647-660

Accredited SINTA SK.NOMOR 28/E/KPT/2019

Open Access at:http://ojs.uho.ac.id/index.php/PUBLICUHO/index

DOI: 10.35817/jpu.v4i2.18090

\section{HASIL DAN PEMBAHASAN}

Kebijakan atau sering kita dengar dengan istilah policy adalah rangkaian konsep yang menjadi pedoman dan dasar rencana dalam pelaksanaan suatu pekerjaan, kepemimpinan, dan cara bertindak. Istilah ini dapat diterapkan pada pemerintahan, organisasi dan kelompok sektor swasta, serta individu. Menurut Parsons dikutip Muadi, dkk. (2016) Kebijakan publik merupakan sebuah proses yang terus menerus, karena itu yang paling penting adalah siklus kebijakan. Siklus kebijakan meliputi formulasi, implementasi dan evaluasi kebijakan. Lebih lanjut menut Anggara (2016: 537) Implementasi kebijakan publik pada umumnya diserahkan kepada lembaga-lembaga pemerintahan dalam berbagai jenjangnya hingga pemerintahan yang terendah. Di samping itu, setiap pelaksanaan kebijakan publik masih memerlukan pembentukan kebijakan dalam wujud peraturan perundang-undangan. Suatu proses implementasi kebijakan merupakan kebijakan publik. Berdasarkan beberapa pengertian tentang kebijakan publik, maka dapat dikatakan bahwa kebijakan publik merupakan suatu bentuk peraturan dan dapat diartikan sebagai hukum yang dirumuskan, disusun serta disepakati oleh pihak berwenang dalam hal ini pemerintah dengan tujuan untuk mengatur kehidupan masyarakat agar dapat sesuai dengan yang dicita-citakan bersama.

Implementasi merupakan salah satu tahap dalam proses kebijakan. Implementasi dilaksanakan setelah sebuah kebijakan dirumuskan dengan tujuan yang jelas. Implementasi merupakan salah satu tahap dalam proses kebijakan publik, biasanya implementasi dilaksanakan setelah sebuah kebijakan dirumuskan dengan tujuan yang jelas (Wahyudi 2016). Lebih lanjut menurut Solichin (2015) implementasi kebijakan mengacu pada sistem pengelolaan urusan-urusan publik (Administrative Governance). Pengelolaan urusan-urusan publik diwujudkan dalam bentuk Good Governance yang memerlukan adanya reformasi kelembagaan dan reformasi manajemen publik. Jadi dapat dikatakan Implementasi kebijakan merupakan tahapan yang sangat penting dalam proses kebijakan. Artinya implementasi kebijakan menentukan keberhasilan suatu proses kebijakan dimana tujuan serta dampak kebijakan dapat dihasilkan. Implementasi kebijakan pada dasarnya menurut Jones (1991) dalam La Ode Muhammad Elwan, (2011: 18) menjelaskan bahwa Implementasi kebijakan mudah dimengerti secara teoritik dan konseptual, namun tidak senantiasa demikian dalam bentuknya yang kongkrit, karena pelaksanaannya secara nyata bukanlah sesuatu yang mudah (Supriadin et al., 2020)

Sesuai dengan hasil penelitian yang di dapat dalam pelaksanaan Implementasi Peraturan Daerah Kabupaten Sidoarjo No. 1 Tahun 2018 Pasal 3 Tentang Pengelolaan Pasar Rakyat dengan menggunakan teori implementasi yang telah dipilih untuk menjadi dasar dari baik atau tidaknya suatu kebijakan. Dalam penelitian ini teori yang digunakan adalah teori 
implementasi Edward III. Dimana didalam teori tersebut terdapat 4 fokus yang mempengaruhi tentang keberhasilan suatu kebijakan. Fokus tersebut meliputi Komunikasi, Sumber Daya, Diposisi dan Struktur Birokrasi. Berdasarkan hasil yang peneliti temukan dilapangan dan didasarkan pada teori implementasi kebijakan Edward III dalam (Agustino 2019) antara lain:

\section{Komunikasi}

Variabel komunikasi menurut Edward III sangat berpengaruh terhadap pencapaian suatu keberhasilan implementasi kebijakan. Penyaluran komunikasi yang efektif akan menghasilkan suatu implementasi yang efektif pula. Persyaratan yang pertama bagi implementasi kebijakan yang efektif adalah bahwa mereka yang melaksanakan keputusan harus mengetahui apa yang harus mereka lakukan. Keputusan-keputusan kebijakan dan perintah-perintah harus diteruskan kepada implementor yang tepat sebelum keputusankeputusan dan perintah-perintah itu dapat diikuti. Komunikasi harus akurat dan harus konsisten dalam melaksanakan setiap kebijakan yang akan diterapkan dalam masyarakat.

Komunikasi antar badan pelaksana merupakan variabel yang sangat mempengaruhi berhasil atau tidaknya kebijakan pengelolaan pasar rakyat ini. Semakin efektif komunikasi yang dilakukan, maka semakin kecil kemungkinan untuk terjadinya kesalahan penyerapan informasi yang disampaikan. Seringkali terjadi masalah dalam penyaluran komunikasi yaitu adanya salah pengertian yang disebabkan kurang jelasnya informasi yang disampaikan. Agar tujuan implementasi kebijakan pengelolaan pasar rakyat dapat tercapai dengan maksimal, dibutuhkan komunikasi yang efektif antara pemerintah, pihak pengelola dan pedagang pasar.

Berdasarkan fakta di lapangan dan berdasarkan sub fokus komunikasi yaitu Transmisi, Kejelasan dan Konsistensi menurut hasil penelitian masih berjalan belum maksimal, yaitu belum terwujudnya program-program di tingkat bawah karena faktor kemampuan personal dalam kejelasan menerima suatu informasi sehingga hal tersebut berdampak pada penerimaan sebuah informasi oleh pelaksana kebijakan menjadi belum maksimal. Hal ini disebabkan rapat atau pertemuan antar pelaksana kebijakan yakni pihak pengelola pasar dengan Dinas Perindustrian dan Perdagangan Kabupaten Sidoarjo tidak dilaksanakan secara rutin. Karena para pelaksana kebijakan masih membutuhkan peran pemerintah untuk memahami dan menjalankan tugas dan kewajibannya sesuai peraturan.

\section{Sumber Daya}

Variabel sumber daya dalam implementasi kebijakan juga berperan penting untuk mencapai keberhasilan suatu implementasi. Dimana dalam hal ini perintah-perintah implementasi mungkin diteruskan secara cermat, jelas dan konsisten, tetapi jika para pelaksana kebijakan kekurangan sumber daya yang diperlukan untuk melaksanakan suatu 


\section{Journal Publicuho}

ISSN2621-1351 (online), ISSN 2685-0729 (print)

Volume 4 Number 2 (May-July), (2021)pp. 647-660

Accredited SINTA SK.NOMOR 28/E/KPT/2019

Open Access at:http://ojs.uho.ac.id/index.php/PUBLICUHO/index

DOI: 10.35817/jpu.v4i2.18090

kebijakan, maka implementasi ini cenderung berjalan tidak efektif. Dengan demikian sumber daya dapat merupakan faktor yang penting dalam melaksanakan kebijakan publik. Pelaksanaan kebijakan Implementasi Peraturan Daerah Kabupaten Sidoarjo No. 1 Tahun 2018 Pasal 3 Tentang Pengelolaan Pasar Rakyat, sumber daya yang ada dapat dikatakan sudah cukup jumlahnya. Terkait tentang petugas yang memiliki rangkap tugas itu merupakan inisiatif sendiri dari petugas sebagai pelaksana.

Sumber daya yang diperlukan dalam suatu kebijakan tidak hanya mengenai sumber daya manusia. Namun, sumber daya juga terkait dengan fasilitas yang disediakan. Pelaksana merupakan faktor penting dalam implementasi kebijakan karena apapun jenis kebijakan pasti sangat memerlukan dukungan dari para pelaksana. Para pelaksana diharapkan paham dan mengetahui tujuan dari pelaksanaan kebijakan. Tidak hanya dukungan staf dan para pelaksana, dukungan fasilitas, serta dukungan sarana dan prasarana juga sangat penting untuk kelancaran suatu implementasi kebijakan.

Dalam pelaksanaan kebijakan pengelolaan pasar rakyat ini jumlah sumber daya manusia yang digunakan oleh Dinas Perindustrian dan Perdagangan Kabupaten Sidoarjo sudah cukup memadai untuk melakukan tugas dan kewajibannya sesuai aturan yang berlaku dan kinerja petugas pelaksana sudah cukup baik. Namun di Pasar Buduran masih terdapat petugas yang merangkap tugasnya yaitu petugas kemanan yang merangkap juga sebagai petugas kebersihan. Tetapi hal tersebut merupakan inisiatif dari petugas sendiri agar dapat mempercepat kinerja petugas kebersihan pasar.

Sedangkan dari segi fasilitas yang ada di Pasar Buduran masih dirasa kurang dan kondisinya tidak baik. Berdasarkan fakta di lapangan di Pasar Buduran belum terdapat fasilitas seperti: lahan pakir, ruang peribadatan, pos keamanan, dan tempat pembuangan sampah yang memadai. Kondisi toilet pasar tidak terawat dan hanya dibiarkan seadanya saja padahal kondisi didalam toilet kotor dan juga tidak ada penerangan. Drainase (saluran air) yang tersedia juga tidak berfungsi dengan baik, hal ini terlihat pada saat musim penghujan Pasar Buduran yang masih mengalami banjir akibat saluran drainase yang tidak berfungsi dengan baik. Atap yang berlubang dan juga kondisi fisik pasar yang kurang terawat juga merupakan bukti fasilitas di Pasar Buduran dirasa masih kurang dan belum memadai.

Para pedagang di Pasar Buduran juga sudah menyampaikan aspirasi mereka terhadap fasilitas pasar yang masih kurang ini kepada petugas pengelola pasar. Dan pengelola pasar pun juga sudah melaporkan kepada pihak terkait namun sampai saat ini belum ada tindakan lebih lanjut dari Pemerintah. Karena untuk menciptakan tujuan yaitu eksistensi pasar tradisional dan pasar yang nyaman bagi pengunjung dibutuhkan fasilitas yang cukup dan memadai yang terdapat pada suatu pasar. Dukungan yang lebih penting 
berasal dari masyarakat terhadap Pasar Buduran adalah peran masyarakat dalam menghidupkan aktivitas pasar yang diwujudkan dengan minat berbelanja di pasar tradisional.

Dari uraian diatas dapat diketahui bahwa sumber daya manusia yang dibutuhkan telah memadai dan kinerja petugas pelaksana sudah cukup baik. Meskipun kinerja para petugas sudah cukup baik namun diharapkan petugas pengelola Pasar Buduran tetap memperhatikan setiap tugas pokok dan fungsi dalam melakukan pengelolaan pasar terhadap Pasar Buduran. Namun, sumber daya berupa fasilitas penunjang pasar masih kurang dan perlu adanya perbaikan dan perawatan berkala sehingga tidak ada lagi keluhan-keluhan baik dari pedagang maupun pengunjung pasar untuk mendukung kelancaran pelaksanaan kebijakan pengelolaan pasar rakyat di Kabupaten Sidoarjo.

\section{Disposisi}

Dalam suatu implementasi kebijakan, sikap atau disposisi petugas pelaksana sangat menentukan efektivitas implementasi kebijakan. Sikap atau disposisi implementor mencakup respon implementor terhadap kebijakan yang terkait dengan kemavan implementor untuk melaksanakan kebijakan publik. Dalam melaksanakan suatu kebijakan harus didukung dengan adanya petugas pelaksana yang memiliki kompetensi dan kapasitas demi keberhasilan kebijakan tersebut.

Agar pelaksanaan suatu kebijakan dapat berjalan dengan baik maka sikap dari pelaksana kebijakan sangat berpengaruh dalam implementasi kebijakan. Apabila implementor memiliki sikap yang baik maka dia akan dapat menjalankan kebijakan dengan baik seperti apa yang diinginkan oleh pembuat kebijakan, sebaliknya apabila sikapnya tidak mendukung maka implementasi kebijakan tidak akan terlaksana dengan baik.

Dalam pelaksanaan di lapangan sikap para pelaksana kebijakan yang sudah cukup baik dalam melaksanakan tugas sesuai dengan aturan yang sudah ditetapkan. Hal tersebut karena penunjukan dan pengangkatan staf dalam birokrasi sudah sesuai dengan kemampuan, kapabilitas, dan kompetensinya sudah dilakukan dengan cukup baik. Hal lain yang juga mempengaruhi sikap para pelaksana kebijakan adalah pemberian intensif kepada para pegawai. Namun pemberian intensif ini hanya untuk pegawai ASN saja, jadi pegawai non-ASN tidak mendapatkan intensif tersebut. Meskipun sikap para pelaksana kebijakan sudah cukup baik namun diharapkan petugas pengelola Pasar Buduran lebih responsif dalam menanggapi setiap keluhan yang disampaikan oleh pedagang dan masyarakat.

\section{Struktur Birokrasi}

Struktur birokrasi merupakan salah satu variabel yang mempengaruhi keberhasilan suatu implementasi kebijakan. Birokrasi yang dimaksudkan adalah tatakelola pemerintahan 


\section{Journal Publicuho}

ISSN2621-1351 (online), ISSN 2685-0729 (print)

Volume 4 Number 2 (May-July), (2021)pp. 647-660

Accredited SINTA SK.NOMOR 28/E/KPT/2019

Open Access at:http://ojs.uho.ac.id/index.php/PUBLICUHO/index

DOI: 10.35817/jpu.v4i2.18090

dengan melibatkan aparatur/pegawai untuk memenuhi pelayanan publik. Termasuk bagaimana mengelola Pasar Rakyat Pada Pasar Buduran Kabupaten Sidoarjo. Maka tentunya diharapkan pelayanan yang dilakoni aparat birokrasi dapat memenuhi kebutuhan pengguna layanan. Menurut Dwiyanto (2006:56) yang dikutip dari La Ode Muhammad Elwan. (2019) bahwa pemberian pelayanan publik oleh aparatur pemerintah kepada masyarakat (publik) merupakan perwujudan dan fungsi aparatur negara sebagai pelayan masyarakat (abdi), disamping sebagai abdi negara. Dalam konteks ini masyarakatlah sebagai aktor utama (pelaku) pembangunan, sedangkan pemerintah berkewajiban untuk mengarahkan, membimbing serta menciptakan suasana yang menunjang kegiatankegiatan dari masyarakat tersebut. Pada kondisi ini aparatur negara dituntut untuk lebih mampu memperbaiki kinerjanya (pelayanan prima) dan diharapkan lebih mampu merumuskan konsep atau menciptakan iklim yang kondusif, sehingga sumber daya pembangunan dapat menjadi pendorong percepatan terwujudnya masyarakat yang mandiri dan sejahtera. Pelayanan yang telah menunjuk kepada aturan formal dianggap telah memenuhi sendi-sendi pelayanan yang baik dan aparat pelayanan dianggap telah konsisten dalam menerapkan aturan hukum pelayanan. (Muhammad Elwan, 2019)

Menurut Edward III, ada dua karakteristik utama dari birokrasi, yakni prosedur-prosedur kerja atau sering disebut sebagai Standart Operational Procedure (SOP) dan juga fragmentasi. Karakteristik yang pertama adalah prosedur-prosedur kerja atau sering disebut Standart Operational Procedure (SOP). SOP menjadi pedoman bagi setiap petugas pelaksana dalam bertindak agar dalam pelaksanaan kebijakan tidak melenceng dari tujuan dan sasaran kebijakan.

Karakteristik yang kedua adalah fragmentasi. Pelaksanaan fragmentasi merupakan upaya penyebaran tanggung jawab kegiatan-kegiatan atau aktifitas-aktifitas pegawai di antara beberapa unit kerja. Jadi suatu implementasi kebijakan membutuhkan pambagian tugas dari beberapa unit untuk melaksanakannya. Kerjasama antar unit sangat mendukung implementasi kebijakan. Pembagian tugas semacam ini akan lebih efektif karena melibatkan semua pihak.

Pada pelaksanaan kebijakan pengelolaan pasar rakyat dalam melaksanakan tugas dan tanggungjawab sudah sesuai dengan prosedur kerja yang sudah ada dan Standar Operasional Prosedur (SOP) sudah diterapkan dengan baik. Namun saat ini SOP untuk pelaksanaan pengelolaan pasar rakyat masih dalam proses pembaharuan dan saat ini masih memakai SOP yang lama. Hal tersebut dikarenakan dahulu Dinas Pasar merupakan lembaga tersendiri namun saat ini sudah merger dengan Dinas Perindustrian dan Perdagangan Kabupaten Sidoarjo dan sudah menjadi satu lembaga pemerintahan.

Pada pelaksanaan fragmentasi atau penyebaran tanggung jawab kegiatan- 
kegiatan atau aktivitas-aktivitas pegawai di antara beberapa unit kerja sudah melakukan pembagian tugas dari beberapa unit sesuai dengan struktur birokrasi Bidang Pasar Rakyat Disperindag Kabupaten Sidoarjo. Untuk melaksanakan kebijakan, setiap unit pelaksana kebijakan sudah mempunyai tugas dan fungsinya masing-masing.

\section{KESIMPULAN}

Berdasarkan hasil penelitian, terkait dengan Implementasi Kebijakan Pengelolaan Pasar Rakyat Pada Pasar Buduran Kabupaten Sidoarjo dilihat dari empat fokus yang sesuai dengan teori implementasi George C. Edward III dapat disimpulkan:

1. Implementasi berdasarkan variabel komunikasi yang meliputi transmisi, kejelasan, konsistensi. Didalam variabel komunikasi ini masih ditemukan sedikit kendala, yaitu terkait kejelasan penyampaian informasi kepada pelaksana kebijakan yaitu belum terwujudnya program-program di tingkat bawah karena faktor kemampuan personal dalam kejelasan menerima suatu informasi sehingga hal tersebut berdampak pada penerimaan sebuah informasi oleh pelaksana kebijakan menjadi belum maksimal. Hal ini dikarenakan rapat atau pertemuan antar pelaksana kebijakan yakni pihak pengelola pasar dengan Dinas Perindustrian dan Perdagangan Kabupaten Sidoarjo tidak dilaksanakan secara rutin.

2. Implementasi berdasarkan variabel sumber daya yang meliputi sumber daya manusia, wewenang, fasilitas dan informasi. Dalam indikator sumber daya manusia yang dibutuhkan telah memadai dan kinerja petugas pelaksana sudah cukup baik. Namun, sumber daya berupa fasilitas penunjang pasar masih kurang karena masih terdapat fasilitas yang tidak tersedia seperti musholla, tempat parkir, dan pos kemanan. Serta masih banyak fasilitas pasar yang tidak terawat maka perlu adanya perbaikan dan perawatan.

3. Implementasi berdasarkan variabel disposisi yang meliputi efek disposisi, pengaturan birokrasi, dan intensif. Dalam pelaksanaan di lapangan sikap para pelaksana kebijakan yang sudah cukup baik dalam melaksanakan tugas sesuai dengan aturan yang sudah ditetapkan. Hal tersebut dikarenakan penunjukan dan pengangkatan staf dalam birokrasi sudah sesuai dengan kemampuan, kapabilitas, dan kompetensinya sudah dilakukan dengan cukup baik. Hal lain yang juga mempengaruhi sikap para pelaksana kebijakan adalah pemberian intensif kepada para pegawai. Namun pemberian intensif ini hanya untuk pegawai ASN saja, jadi pegawai non-ASN tidak mendapatkan intensif tersebut.

4. Implementasi berdasarkan struktur birokrasi yang meliputi Standar Operasional Prosedur (SOP) dan fragmentasi. Para petugas pelaksana dalam melaksanakan tugas dan tanggungjawab sudah sesuai dengan prosedur kerja atau Standar Operasional Prosedur 


\section{Journal Publicuho}

ISSN2621-1351 (online), ISSN 2685-0729 (print)

(SOP) yang sudah ada dan diterapkan dengan baik. Pada pelaksanaan fragmentasi atau penyebaran tanggung jawab kegiatan-kegiatan atau aktifitas-aktifitas pegawai di antara beberapa unit kerja. Para pelaksana kebijakan juga sudah melakukan pembagian tugas dari beberapa unit sesuai dengan struktur birokrasi. Namun, saat ini SOP yang digunakan dalam pelaksanaan kebijakan pengelolaan pasar rakyat masih dalam proses pembaharuan dan saat ini masih memakai SOP yang lama.

\section{REFERENSI}

Agustino, Leo. 2019. Dasar - Dasar Kebijakan Publik. Bandung: Alfabeta.

Efendi, Rusman, and Jihan Nada Alya Syifa. 2019. "Status Kesehatan Pasar Ditinjau Dari Aspek Sanitasi Dan Perilaku Hidup Bersih Sehat (PHBS) Pada Pasar Ciputat Dan Pasar Modern BSD Kota Tangerang Selatan." Jurnal Kesehatan Indonesia 9(3): 122.

Martha, Ignatia, and Nuruni Ika. 2019. "Penataan Pasar Rakyat Dan Pasar Modern Di Kota Surabaya." JDEP (Jurnal Dinamika Ekonomi Pembangunan) 2(2): 186-91.

Masitoh, Eis Al. 2013. "Upaya Menjaga Eksistensi Pasar Tradisional: Studi Revitalisasi Pasar Piyungan Bantul." Jurnal PMI X(2): 63-78.

Muadi, Sholih, Ismail MH, and Ahmad Sofwani. 2016. "Konsep Dan Kajian Teori Perumusan Kebijakan Publik." Jurnal Review Politik 6(2): 195-224.

http://jurnalpolitik.uinsby.ac.id/index.php/jrp/article/view/90.

Muhammad Elwan, L. O. (2019). PROBLEM BIROKRASI DALAM MENINGKATAN PELAYANAN PUBLIK PADA SEKRETARIAT DAERAH KABUPATEN MUNA. Journal Publicuho. https://doi. org/10.35817/jpu. v2i2, 7223.

Mujianto Solichin. 2015. "Implementasi Kebijakan Pendidikan Dan Peran Birokrasi." Studi Islam 6(1978-306X): 148-78.

Natsir, M. 2017. "Implementasi Kebijakan Pengelolaan Pasar Tradisional Milik Pemerintah Kabupaten Mamuju Utara (the Implementation of Management Policies on Traditional Market Own By Goverment in Kabupaten Mamuju Utara)." Asian Journal of Environment 1(1): 61-76.

Sahya Anggara. 2016. Ilmu Administrasi Negara. Bandung: CV. PUSTAKA SETIA.

Saputra, Ogi Ginanjar, Awan Mutakin, and Rimayanti LN. 2019. "Peranan Pasar Kaget Dalam Upaya Mengurangi Angka Pengangguran Di Kecamatan Ciparay Kab. Bandung." Geoarea 2(1).

Shidiq, Umar, and Miftachul Choiri. 2019. 53 Journal of Chemical Information and Modeling Metode Penelitian Kualitatif Di Bidang Pendidikan. http://repository.iainponorogo.ac.id/484/1/METODE PENELITIAN KUALITATIF DI BIDANG PENDIDIKAN.pdf. 
Sudrajat, Arip Rahman, Asep Sumaryana, Raden Ahmad Buchari, and Tahjan Tahjan. 2018.

"Perumusan Strategi Pengelolaan Pasar Tradisional Di Kabupaten Sumedang." JPPUMA: Jurnal IImu Pemerintahan dan Sosial Politik Universitas Medan Area 6(1): 53.

Supriadin, R., Alam, S., \& Elwan, L. O. M. (2020). IMPLEMENTASI PERATURAN WALIKOTA KENDARI NOMOR 13 TAHUN 2008 TENTANG PENATAAN PEDAGANG KAKI LIMA DI KOTA KENDARI. Journal Publicuho. https://doi.org/10.35817/jpu.v3i1.11506

Wahyudi, Aji. 2016. "Implementasi Rencana Strategis Badan Pemberdayaan Masyarakat Dan Desa Dalam Upaya Pengembangan Badan Usaha Milik Desa Di Kabupaten Kotawaringin Barat." Jurnal Ilmiah Administrasi Publik (JIAP) 2(1): 58-67.

Yuliani, S., B. Sudarsono, and A. Wijaya. 2016. "Aplikasi Sistem Informasi Geografis (Sig) Untuk Pemetaan Pasar Tradisional Di Kota Semarang Berbasis Web." Jurnal Geodesi Undip 5(2): 208-2016. 